\title{
Pengaruh Pemberian Asam Lemak Terproteksi dalam Bentuk Campuran Garam Karboksilat Kering Terhadap Performa dan Metabolit Darah Kambing PE Fase Pertumbuhan
}

\author{
Andi Murlina Tasse ${ }^{1 *}$, La Ode Nafiu ${ }^{1}$, Fanny Yulia Irawan ${ }^{2}$, La Ode Arsad Sani ${ }^{1}$, \\ Harapin Hafid ${ }^{1}$ \\ ${ }^{1}$ Fakultas Peternakan Universitas Halu Oleo \\ Jl. H.E.A. Mokodompit Kampus Hijau Bumi Tridharma, Anduonohu, Kendari 93232 \\ ${ }^{2}$ Alumni Program Pascasarjana Universitas Halu Oleo \\ Kampus Abdullah Silondae, Jl. Mayjend S. Parman, Kendari 93121 \\ *Email korespondensi: andimurlinatasse@gmail.com
}

(Diterima 28-08-2019; disetujui 29-12-2019)

\begin{abstract}
ABSTRAK
Tujuan penelitian ini untuk mengetahui efek pemberian asam lemak terproteksi yang berasal dari hasil samping pengolahan limbah ikan terhadap performa kambing peranakan etawa dalam pertumbuhan. Penelitian dilaksanakan di kandang ternak Desa Alebo, Kabupaten Konawe Selatan dan Laboratorium Ilmu Nutrisi dan Teknologi Pakan, Fakultas Peternakan Universitas Halu Oleo, Kendari. Materi penelitian meggunakan 16 ekor kambing peranakan etawa berumur 4-6 bulan dan bobot badan 10-12 kg. Pakan yang digunakan terdiri atas hijauan dan asam lemak terproteksi (ALT) sebagai campuran garam karboksilat kering (CGKK). Rancangan penelitian adalah rancangan acak lengkap dengan 4 perlakuan dan 4 ulangan. Perlakuan terdiri atas $\mathrm{T} 1=0 \mathrm{~g}$ ALT; $\mathrm{T} 2=200 \mathrm{~g}$ ALT; T3 $=250 \mathrm{~g}$ ALT, dan T4 $=300 \mathrm{~g}$ ALT. Variabel penelitian meliputi kosumsi pakan, pertambahan bobot badan, dan konversi pakan. Hasil penelitian menunjukkan bahwa perlakuan berpengaruh sangat nyata $(\mathrm{P}<0,01)$ terhadap konsumsi pakan, pertambahan bobot badan dan konversi pakan kambing peranakan Etawa fase pertumbuhan. Rataan konsumsi pakan (Kg BK/ekor/minngu) $\mathrm{T} 1=4,58 ; \mathrm{T} 2=5,68 ; \mathrm{T} 3=6,19 ;$ dan $\mathrm{T} 4=6,48$. Rataan pertambahan bobot badan (kg/ekor/minggu) $\mathrm{T} 1=$ $0.43, \mathrm{~T} 2=0.90, \mathrm{~T} 3=1.44$ dan $\mathrm{T} 4=1.42$. Rataan konversi pakan $\mathrm{T} 1=10,63 ; \mathrm{T} 2=7,61$. Disimpulkan bahwa pemberian asam lemak terproteksi (ALT) yang berasal dari hasil sampig pengolahan limbah ikan (200-300 g/ekor/hari) meningkatkan konsumsi bahan kering, pertambahan bobot badan, dan memperbaiki efisiensi konversi pakan kambing peranakan etawa fase pertumbuhan.
\end{abstract}

Kata kunci: asam lemak terproteksi, kambing PE, performa,

\begin{abstract}
The purpose of this research was to know the effect of applying protected fatty acids originated from by-product of fish processing on performance growth phase ettawa crossbred. The study was conducted at Cattle Pen located at Alebo village, South Konawe Regency, and Laboratory of Nutrition Science and Feed Technology, Faculty of Animal Science, Halu Oleo University, Kendari. The materials used 16 Etawa crossbred aged 4-6 months and weighed 10-12 kg. The feeds were applied consist of roughage and protected fatty acid (PFA), as dry carboxylate salt mixture, DCM. The research design was Complete Randomized Design with 4 treatments and 4 repeatition. The treatments were $\mathrm{T} 1=0 \mathrm{~g}$ PFA; $\mathrm{T} 2=200 \mathrm{~g}$ PFA; T3 $=250 \mathrm{~g}$ PFA; and T4 $=300 \mathrm{~g}$ PFA. Variable were feed intake, gain, and feed conversionl. The results of research showed that the treatments had a very significant effect $(\mathrm{P}<0.01)$ on the feed consumption, weekly gain, and feed conversion on the growth phase. The average feed consumption (kg dry mater/head/week) $\mathrm{T} 1=4.58 ; \mathrm{T} 2$ $=5.68 ; \mathrm{T} 3=6.19 ;$ and $\mathrm{T} 4=6.48$. The concluded that application of protected fatty acid (PFA), originated from by-product of fish processing (200-300 $\mathrm{g} /$ head/day) increased dry matter intake, weekly gain, and improved feed conversion efficiency etawa crossbred.
\end{abstract}

Keywords: ettawa crossbred, performance, protected fatty acid 


\section{PENDAHULUAN}

Pemeliharaan ternak kambing di Sulawesi Tenggara umumnya masih dilakukan secara konvensional misalnya pemberian pakan hanya berupa hijauan, sehingga produktivitasnya kurang optimal. Hal ini berdampak terhadap pendapatan peternak yang belum dapat memberikan pendapatan yang memadai.

Pertumbuhan kambing dapat dipercepat melalui penggunaan pakan penguat atau pakan tambahan. Pertambahan bobot badan akan dapat dicapai apabila pakan yang diberikan terdiri atas hijauan dan pakan tambahan (Rostini, 2011). Penambahan pakan tambahan ke dalam pakan ternak kambing yang sedang tumbuh dapat meningkatkan pertambahan bobot badan 50-80 g/ekor/hari dan palatabilitas pakan yang dikonsumsi (Martawidjaja et al., 1999).

Selama dekade terakhir, salah satu pakan tambahan yang sering digunakan adalah asam lemak terproteksi yang berasal dari hasil ikutan pengolahan ikan. Namun demikian, bahan baku yang digunakan untuk pembuatan produk ini adalah minyak ikan yang dijual secara komersial, padahal di Sulawesi Tenggara salah satu bahan pakan alternatif yang dapat dimanfaatkan sebagai bahan baku untuk pembuatan asam lemak terproteksi adalah limbah pengolahan ikan tuna berupa kepala, sirip, isi perut dan ekor. Pemasakan hasil ikutan tersebut dapat diperoleh minyak ikan.

Penggunaan asam lemak terproteksi bertujuan untuk mencukupi ketidakcukupan kandungan nutrien dalam pakan hijauan yang diberikan pada ternak (Chen et al., 2014). Asam lemak terproteksi dalam pakan dapat meningkatkan produktivitas ternak, meningkatkan efisiensi pakan, meningkatkan asam lemak tidak jenuh dalam daging, meningkatkan kinerja reproduksi, dan meningkatkan produksi susu (Wina \& Susana, 2013).

Hasil penelitian tentang efek penggunaan asam lemak terproteksi dalam pakan terhadap performa dan produksi kambing yang sedang tumbuh belum banyak dilaporkan dalam jurnal ilmiah nasional. Oleh karena itu, perlu dilakukan penelitian untuk mengkaji efek penggunaan asam lemak terproteksi terhadap kinerja pertumbuhan meliputi perfomans dan metabolit darah kambing jantan lokal yang sedang tumbuh.

\section{MATERI DAN METODE}

Penelitian ini dilaksanakan selama 4 bulan di Kandang Ternak Metabolis yang terletak di desa Alebo, Kabupaten Konawe Selatan, sebagai tempat pemeliharaan kambing selama penelitian. Sedangkan pembuatan asam lemak terproteksi dilakukan di Laboratorium Nutrisi dan Teknologi Pakan Fakultas Peternakan Universitas Halu Oleo, Kendari.

Bahan yang digunakan dalam penelitian ini terdiri atas kambing lokal jantan umur 4-6 bulan sebanyak 16 ekor dengan kisaran bobot badan 10$12 \mathrm{~kg}$, dedak padi, limbah hasil ikutan pengolahan ikan (kepala, ekor, tulang dan isi perut) asam klorida, $\mathrm{NaOH}, \mathrm{CaCL}_{2}$, dan Onggok.

Peralatan yang digunakan pada penelitian adalah kandang metabolis (kandang individu) model panggung berukuran $90 \mathrm{~cm} \times 90 \mathrm{~cm}$, masing-masing petak dilengkapi dengan tempat makan dan minum dan juga digunakan peralatan lain seperti ember, garpu kayu (penarik feses), timbangan, kantong plastik. Sedangkan alat yang digunakan untuk pembuatan asam lemak terproteksi antara lain: kompor, panci, batang pengaduk, gelas ukur, kertas $\mathrm{pH}$, dan oven listrik.

Pembuatan asam lemak terproteksi (campuran garam karboksilat kering, CGKK) berbahan baku minyak ikan hasil samping pegalegan ikan. Minyak ikan dihidrolisis secara bertingkat asam degan asam khlorida lalu hidrolisis basa dengan $\mathrm{NaOH}$. Hasil hidrolisis berupa garam karboksilat dicampur dengan larutan $\mathrm{CaCL}_{2}$, lalu dicampur dengan onggok. Selanjutnya campuran ini dikeringkan dalam oven bersuhu $32^{\circ} \mathrm{C}$.

Variabel meliputi konsumsi bahan kering pakan, pertumbuhan bobot badan, dan konversi pakan. Rancangan percobaan yang digunakan dalam penelitian adalah Rancangan Acak Lengkap (RAL) dengan 4 perlakuan dan 4 ulangan. Jika perlakuan menunjukkan pengaruh yang nyata, maka analisis data dilanjutkan dengan uji Student Newman Keuls Test (SNKT).

\section{HASIL DAN PEMBAHASAN}

\section{Konsumsi Bahan Kering (BK)}

Rataan konsumsi BK hijauan dan asam lemak terproteksi kambing jantan lokal ( $\mathrm{kg}$ BK/ekor/minggu) dapat dilihat pada Tabel 1. 
Tabel 1. Rataan konsumsi BK hijauan dan asam lemak terproteksi kambing jantan lokal (kg BK/ekor/minggu)

\begin{tabular}{cccccc}
\hline \multirow{2}{*}{ Minggu } & \multicolumn{3}{c}{ Perlakuan } & \multirow{2}{*}{ SEM } \\
\cline { 2 - 4 } & P1 & P2 & P3 & P4 & 0,009 \\
2 & $4,57^{\mathrm{d}}$ & $5,85^{\mathrm{c}}$ & $6,19^{\mathrm{b}}$ & $6,52^{\mathrm{a}}$ & 0,006 \\
3 & $4,58^{\mathrm{d}}$ & $5,86^{\mathrm{c}}$ & $6,18^{\mathrm{a}}$ & $6,52^{\mathrm{b}}$ & 0,008 \\
4 & $4,58^{\mathrm{d}}$ & $5,87^{\mathrm{c}}$ & $6,20^{\mathrm{b}}$ & $6,52^{\mathrm{a}}$ & 0,046 \\
5 & $4,58^{\mathrm{d}}$ & $5,88^{\mathrm{c}}$ & $6,22^{\mathrm{b}}$ & $6,40^{\mathrm{a}}$ & 0,008 \\
6 & $4,58^{\mathrm{d}}$ & $5,86^{\mathrm{c}}$ & $6,18^{\mathrm{b}}$ & $6,50^{\mathrm{a}}$ & 0,048 \\
7 & $4,57^{\mathrm{d}}$ & $5,85^{\mathrm{c}}$ & $6,19^{\mathrm{b}}$ & $6,41^{\mathrm{b}}$ & 0,007 \\
\hline Rataan & $4,58^{\mathrm{d}}$ & $5,87^{\mathrm{c}}$ & $6,17^{\mathrm{b}}$ & $6,49^{\mathrm{a}}$ & 0,010 \\
\hline
\end{tabular}

Superskrip yang berbeda pada baris yang sama menunjukkan pengaruh antar perlakuan berbeda sangat nyata $(\mathrm{P}<0,01) . \mathrm{SEM}=$ standard error of the mean

Tabel 1 menunjukkan bahwa pengguna-an asam lemak terproteksi berpengaruh sangat nyata $(\mathrm{P}<0,01)$ terhadap konsumsi ransum mulai minggu ke-1 sampai minggu ke-7 pengamatan. Hasil uji SNK menunjukkan bahwa semua level pemberian ALT berbeda sangat nyata satu sama lain, terutama terhadap kontrol $(\mathrm{P} 1)$. Konsumsi bahan kering (6,48 $\mathrm{kg}$ BK/ekor/minggu) yang dihasilkan dari pem-berian ALT sebanyak 300 g/ekor/hari paling tinggi dibandingkan dengan pemberian ALT sebanyak 250 g/ekor/hari, 200 g/ekor/hari dan tanpa pemberian ALT. Hal ini menunjukkan bahwa pemberian ALT 200-300 g/ekor/hari mampu meningkatkan palatabilitas pakan sehingga konsumsi bahan kering meningkat.

Pemberian pakan tersuplementasi sabun kalsium (Ca-soap) sebagai ALT dengan bahan baku minyak dedak padi mampu meningkatkan konsumsi bahan kering pada kambing dalam masa pertumbuhan (Bhatt et al., 2013). Visualisasi rataan konsumsi hijauan dan ALT kambing jantan lokal selama penelitian dapat dilihat pada Gambar 1.

Peningkatan konsumsi pakan menujuk-kan bahwa asam-asam lemak yang terproteksi menyebabkan laju pakan melewati rumen dipercepat sehingga rumen cepat kosong, yang memicu ternak untuk mengisi rumen melalui asupan pakan. Hal ini akan berdampak pada peningkatan ketersediaan energi untuk memenuhi kebutuhan produksi atau peningkatan bobot badan pada kambing dalam fase pertumbuhan.

\section{Pertambahan Bobot Badan}

Tabel 2 menunjukkan bahwa penggunaan asam lemak terproteksi berpengaruh sangat nyata $(\mathrm{P}<0,01)$ terhadap pertambahan bobot badan per minggu mulai minggu ke-1 sampai minggu ke-7 pengamatan. Hasil uji SNK menunjukkan bahwa semua level pemberian asam lemak terproteksi berbeda nyata satu sama lain, terutama terhadap kontrol (P1). Rataan pertambahan bobot badan per minggu 1,44 $\mathrm{kg} /$ ekor/minggu dan 1,42 kg/ekor/minggu yang dihasilkan dari pemberian asam lemak terproteksi sebanyak $250 \mathrm{~g} / \mathrm{ekor} / \mathrm{hari}$ dan 300 g/ekor/hari paling tinggi dibandingkan dengan pemberian asam lemak terproteksi sebanyak 200 g/ekor/hari dan tanpa pemberian asam lemak terproteksi. Hal ini menunjukkan bahwa pemberian asam lemak terproteksi 250 g/ekor/hari dan 300 g/ekor/hari mampu menyediakan energi untuk sintesa protein jaringan tubuh yang diekspresikan dalam peningkatan bobot badan. Visualisasi rataan bobot badan kambing jantan lokal selama penelitian pada level pemberian ALT yang berbeda dapat dilihat pada Gambar 2.

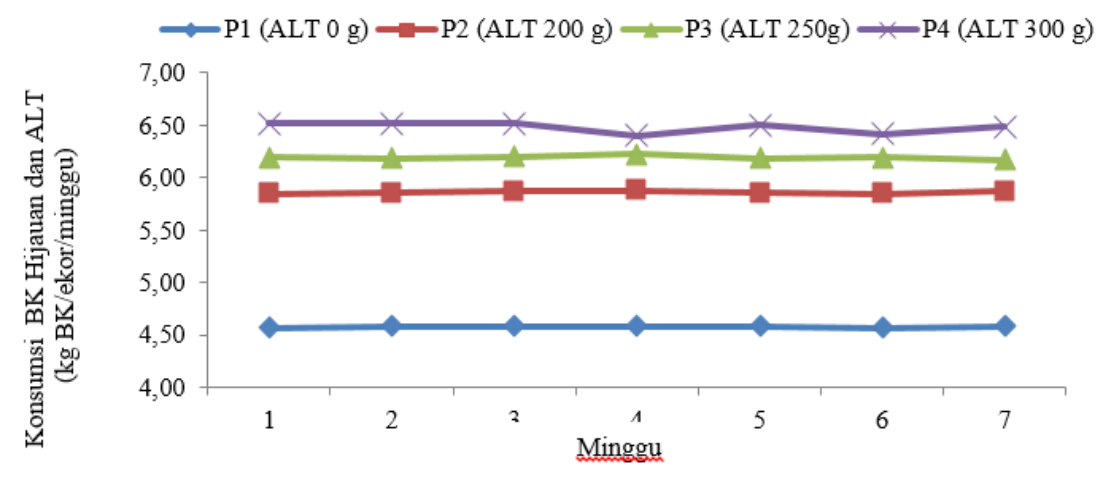

Gambar 1. Grafik rataan konsumsi BK hijauan dan ALT kambing jantan lokal 
Tabel 2. Rataan pertambahan bobot badan per minggu kambing jantan lokal (kg/ekor/minggu)

\begin{tabular}{ccccc}
\hline \multirow{2}{*}{ Minggu } & \multicolumn{3}{c}{ Perlakuan } \\
\cline { 2 - 5 } & $\mathrm{P} 1$ & $\mathrm{P} 2$ & $\mathrm{P} 3$ & $\mathrm{P} 4$ \\
\hline 1 & $0,43^{\mathrm{b}}$ & $1,43^{\mathrm{a}}$ & $1,43^{\mathrm{a}}$ & $1,45^{\mathrm{a}}$ \\
2 & $0,45^{\mathrm{c}}$ & $0,92^{\mathrm{b}}$ & $1,40^{\mathrm{a}}$ & $1,50^{\mathrm{a}}$ \\
3 & $0,41^{\mathrm{c}}$ & $0,78^{\mathrm{b}}$ & $1,49^{\mathrm{a}}$ & $1,61^{\mathrm{a}}$ \\
4 & $0,53^{\mathrm{c}}$ & $0,79^{\mathrm{b}}$ & $1,48^{\mathrm{a}}$ & $1,26^{\mathrm{a}}$ \\
5 & $0,37^{\mathrm{c}}$ & $0,79^{\mathrm{b}}$ & $1,42^{\mathrm{a}}$ & $1,47^{\mathrm{a}}$ \\
6 & $0,41^{\mathrm{c}}$ & $0,92^{\mathrm{b}}$ & $1,35^{\mathrm{a}}$ & $1,44^{\mathrm{a}}$ \\
7 & $0,44^{\mathrm{d}}$ & $0,87^{\mathrm{c}}$ & $1,52^{\mathrm{a}}$ & $1,23^{\mathrm{b}}$ \\
\hline Rataan & $0,43^{\mathrm{c}}$ & $0,90^{\mathrm{b}}$ & $1,44^{\mathrm{a}}$ & $1,42^{\mathrm{a}}$ \\
\hline
\end{tabular}

Superskrip yang berbeda pada baris yang sama menunjukkan pengaruh antar perlakuan berbeda sangat nyata $(\mathrm{P}<0,01)$

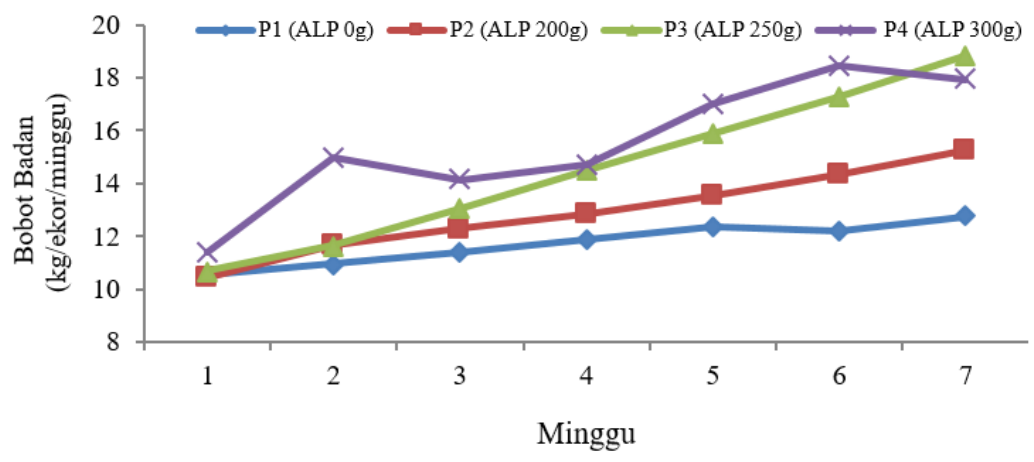

Gambar 5. Grafik rataan bobot badan per minggu kambing jantan lokal

Rataan pertambahan bobot badan yang diperoleh dari perlakuan P3 (250 g ALT) adalah $1,44 \mathrm{~kg} / \mathrm{ekor} / \mathrm{minggu}$ atau $205,71 \mathrm{~g} / \mathrm{ekor} / \mathrm{hari}$ dan P4 (300 g ALT) adalah 1,42 kg/ekor/minggu atau $202 \mathrm{~g} / \mathrm{ekor} / \mathrm{hari}$.

Peningkatan pertambahan bobot badan pada pemberian asam lemak terproteksi $250 \mathrm{~g} / \mathrm{ekor} / \mathrm{hari}$ menunjukkan asam-asam terproteksi tidak megalami perombakan dalam rumen tetapi mengalami perombakan dalam abomasum. Selanjutnya asamasam lemak tersebut dapat diabsorbsi di usus halus, dan diangkat oleh kapiler darah, ke target jarigan misalya otot. Peningkatan pertambahan bobot badan tidak hanya ditujukan oleh pertambahan bobot otot, juga meliputi pertambahan bobot komponen tubuh lainnya.

\section{Konversi Pakan}

Rataan nilai konversi pakan kambing jantan lokal dapat dilihat pada Tabel 6. Penggunaan asam lemak terproteksi berpengaruh sangat nyata $(\mathrm{P}<0,01)$ terhadap konversi pakan mulai minggu ke-1 sampai minggu ke-7 pengamatan. Hasil uji SNK menunjukkan bahwa semua level pemberian asam lemak terproteksi berbeda nyata satu sama lain, terutama terhadap kontrol (P1). Rataan konversi pada perlakuan P4 juga nyata lebih tinggi
$(\mathrm{P}<0,01)$ dibandingkan dengan $\mathrm{P} 3$. Konversi pakan 10,75 dan 6,73 yang dihasilkan tanpa pemberian asam lemak terproteksi dan pemberian asam lemak terproteksi hanya $200 \mathrm{~g} / \mathrm{ekor} / \mathrm{hari}$ menghasilkan rataan konversi pakan lebih tinggi dibandingkan dengan pemberian asam lemak terproteksi pada level $250 \mathrm{~g} / \mathrm{ekor} / \mathrm{minggu}$ dan $300 \mathrm{~g} / \mathrm{ekor} / \mathrm{minggu}$.

Semakin kecil nilai konversi pakan menunjukkan penggunaan pakan semakin efisien. Diantara keempat perlakuan pada penelitian ini pakan yang dapat memberikan efektifitas paling baik adalah pada pemberian ALT sebanyak $250 \mathrm{~g}$ (P3) dengan rataan nilai konversi pakan (4,31 dan 4,64), terendah pada pemberian ALT 250 g/ekor/hari dan 300 g/ekor/hari.

Konversi pakan pada ternak ruminansia dipengaruhi oleh kemampuan ternak untuk mencerna bahan pakan, kecukupan nutrisi untuk memenuhi kebutuhan hidup pokok, pertumbuhan dan fungsi-fungsi tubuh yang lain serta jenis bahan pakan yang dikonsumsi (Marjuki, 2008). Konversi pakan pada penelitian ini lebih baik dibandingkan dengan konversi pakan Tanuwiria (2013) sebesar 8.3-11.4 dan Purbowati et al. (2009) nilai konversi pakan berkisar 7,41-8,08. 
Tabel 3. Rataan konversi pakan kambing lokal jantan

\begin{tabular}{|c|c|c|c|c|c|}
\hline \multirow{2}{*}{ Minggu } & \multicolumn{4}{|c|}{ Perlakuan } & \multirow{2}{*}{ SEM } \\
\hline & $\mathrm{P} 1$ & $\mathrm{P} 2$ & P3 & $\mathrm{P} 4$ & \\
\hline 1 & $10,78^{\mathrm{a}}$ & $5,22^{b}$ & $4,33^{c}$ & $4,51^{\mathrm{c}}$ & 0,278 \\
\hline 2 & $10,54^{\mathrm{a}}$ & $6,36^{\mathrm{b}}$ & $4,44^{\mathrm{c}}$ & $4,34^{\mathrm{c}}$ & 0,288 \\
\hline 3 & $11,22^{\mathrm{b}}$ & $6,96^{\mathrm{a}}$ & $4,15^{\mathrm{c}}$ & $4,32^{\mathrm{c}}$ & 0,408 \\
\hline 4 & $8,84^{\mathrm{a}}$ & $7,58^{a}$ & $4,26^{\mathrm{b}}$ & $5,13^{\mathrm{b}}$ & 0,464 \\
\hline 5 & $12,73^{\mathrm{a}}$ & $7,54^{b}$ & $4,34^{c}$ & $4,50^{c}$ & 0,547 \\
\hline 6 & $10,62^{\mathrm{a}}$ & $6,39^{\mathrm{b}}$ & $4,58^{\mathrm{c}}$ & $4,46^{\mathrm{c}}$ & 0,437 \\
\hline 7 & $10,52^{\mathrm{a}}$ & $6,04^{b}$ & $4,06^{c}$ & $5,25^{\mathrm{c}}$ & 0,478 \\
\hline Rataan & $10,75^{\mathrm{a}}$ & $6,73^{b}$ & $4,31^{\mathrm{c}}$ & $4,64^{\mathrm{c}}$ & 0,144 \\
\hline
\end{tabular}

Superskrip yang berbeda pada baris yang sama menunjukkan pengaruh antar perlakuan berbeda sangat nyata $(\mathrm{P}<0,01)$

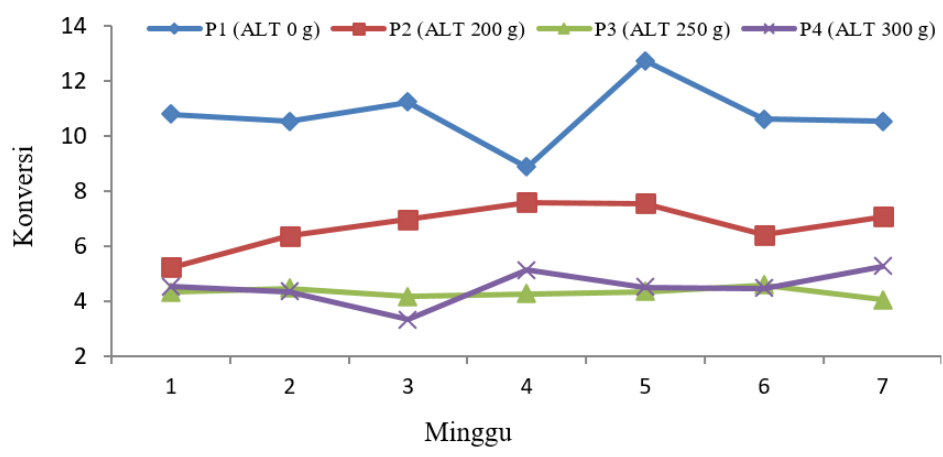

Gambar 6. Grafik rataan konversi pakan kambing jantan lokal

\section{KESIMPULAN}

Berdasarkan hasil pembahasan dapat disimpulkan bahwa pemberian asam lemak terproteksi dalam bentuk campuran garam karboksilat kering sebanyak 200-300 g/ekor/hari mampu meningkatkan konsumsi bahan kering, pertambahan bobot badan serta meningkatkan efisiensi penggunaan pakan yang terlihat dari menurunnya angka konversi pakan.

\section{DAFTAR PUSTAKA}

Bhat, R.S., A. Sahoo, A.K. Shinde, \& S.A. Karim. 2011. Effect of different level of coconut oil supplementation on performace, digestibility, rumen fermentation and carcass traits of Malpura lambs. Anim Feed Sci Technol 164:29-37.

Chen, L., G. Guo, X. Yuan, M. Himojo, C. Yu, \& T. Shao. 2014. Effect of appling molasses and propionic acid on fermentation quality and ascorbic stability of total mixed ration silage prepared with whole-plant corn in Tibet. AJAS 27(3):349-356.

Marjuki, 2008. Penggunaan tepung ikan dalam pakan konsentrat dan pengaruhnya terhadap pertambahan bobot badan kambing betina. Jurnal Ternak Tropika 9:90-100.

Martawidjaja, M., B. Setiadi, \& S.S. Sitorus. 1999. Pengaruh tingkat protein-energi ransum terhadap kinerja produksi kambing kacang muda. Jurnal Ilmu Ternak dan Veteriner 4(3):167-172.

Purbowati, E., Sutrisno, C.I., Baliarti, E., dan Budhi, S.P.S., 2009. Penampilan domba lokal jantan dengan pakan komplit dari berbagai limbah pertanian dan agroindustri. Prosiding Seminar Nasional Kebangkitan Peternakan. Fakultas Peternakan Universitas Diponehoro. Semarang. 20 Mei 2009. Hlm 130-138.

Rostini, T. 2011. Upaya Meningkatan kualitas daging kambing kacang melalui penggunakan silase ransum komplit berbahan baku lokal. Media Sains 3(1).

Tanuwiria, U.H. 2013. Efek suplementasi kompleks mineral-minyak dan mineral organik dalam ransum terhadap kecernaan ransum, populasi mikroba rumen dan performa produksi domba jantan. Seminar Nasional dan Kongres Asosiasi Ahli Nutrisi dan Pakan Ternak Indonesia. Fakultas 
Peternakan Universitas Gadjah Mada. Yogyakarta. 27 Juli 2007. Hlm 327-334.

Wina, E. \& I.W.R. Susana. 2013. Manfaat lemak terproteksi untuk meningkatkan produksi dan reproduksi ternak ruminansia Wartazoa 23(4):176-184. 